UDK 533.9.07, 535.9.082.5

Dragan G.S. ${ }^{1}$, Santonii V.I. ${ }^{2}$, Shingarov G.L. ${ }^{1}$, Rimashevsky O.A. ${ }^{1}$, Kolesnikov K.V. ${ }^{1}$, Shevchenko O.M. ${ }^{3}$, Yanko V.V. ${ }^{2}$

${ }^{1}$ Physics Research Institute Odessa I. I. Mechnikov National University (ONU), Ukraine;

${ }^{2}$ Laboratory of sensors and recording systems ONU;

${ }^{3}$ Kiev Small Academy of Sciences for Student Youth; E-mail:dragan@onu.edu.ua

\title{
Scattering of laser radiation from condensed phase of heterogeneous smoky plasma
}

\begin{abstract}
A technique for research the spatial structures of the condensed phase grains in heterogeneous smoky plasma by determining the laser scattering indicatrix modulated with a frequency of $60 \mathrm{kHz}$ in three spectral intervals was developed. An experimental stand was created to register the laser scattering indicatrix on the wavelengths of $808 \mathrm{~nm}, 630 \mathrm{~nm}$ and $532 \mathrm{~nm}$ in the scattering angles range from 0 to $170^{\circ}$ with a measurement time of 3 seconds. A program of registration and processing of measurement results on a computer has been developed. Tests of the experimental complex on the flame of metalized fuel compositions were carried out.
\end{abstract}

Keywords: Heterogeneous plasma, laser scattering, spatial structures of plasma grains.

Introduction. Contemporary contactless research methods of heterogeneous plasma provide the analysis of the laser radiation intensity scattered by a dispersed component at different angles. Data processing of optoelectronic devices response of the measuring complex to a scattered light signal makes it possible to determine the scattering indicatrix (angular distribution of scattered radiation) and to determine such important parameters of the smoky plasma as the grains size distribution function of the condensed phase, as well as their concentration and spatial distribution $[1,2]$. It is assumed that the time interval for measuring the parameters of the plasma medium is sufficient for the system to be considered quasi-stationary.

In recent decades, after the publication of the first results on the formation of ordered spatial structures of particles in a smoke plasma $[3,4]$ and a number of theoretical works [5,6], interest in such studies has grown significantly, which led to the experimental identification of "plasma crystals" in a gas discharge plasma with monodisperse condensed grains $[7,8]$. The researches of dusty plasma are described in sufficient detail in monograph [9] and other publications. Along with this, only individual scientific works $[10,11]$ are devoted to the physical properties of smoky plasma, and the systemic researches of the mechanisms of charging and interaction of grains were not spent. This is due to the presence of a multifractional dispersed phase, thermodynamic instability and spatial inhomogeneity of plasma parameters. Nevertheless, interest in the properties of smoky plasma is growing due to its use in non-standard technological and power systems. It should also be noted that the effect of displacement of the ionization equilibrium in relation to the quasineutral plasma in smoky plasma is predicted [12], which has not yet received experimental confirma- 
tion. All this stimulates the development of methods and devices for the experimental research of heterogeneous smoky plasma.

Objective of the present work is development a technique for research of laser radiation scattering by the condensed grains of heterogeneous smoky plasma for detecting ordered spatial structures and creation of the automated experimental stand.

Statement of the problem. Following the above brief scientific literature review, it can be concluded that the spatial ordered structures of charged condensed grains in a gas-discharge plasma ("plasma crystals") have been researched in sufficient detail [9]. Along with this, only some publications are devoted to the spatial structures of particles in smoky plasma, despite the fact that they were discovered much earlier [3]. This is due, first of all, to the complexity and variety of processes in smoke plasma [4] (multifractionality of condensed grains, impossibility of direct observation of nanograins, etc.). As shown in $[10,13]$, smoky plasma differs significantly from dusty plasma.

The condensed phase in the smoky plasma is formed directly in the combustion products at a high temperature and therefore can contain three fractions of grains, with the smallest fraction having a size of about ten nanometers, as a result of which the use of optical methods has a number of restrictions. The same applies to grains of the second fraction - about a hundred nanometers. Thus, classical optical methods are applicable only for the third fraction of grains larger than a micron. Along with that, the results of calculations [14] show the possibility of the formation of spatial structures of the micron fraction of grains, and therefore in this working we are focused on the coarse fraction.

Consider the conditions for the appearance and possible registration of an ordered spatial structure of grains of a condensed phase of the "diffraction grating" type in smoky plasma. Let the grains form a volumetric diffraction grating in the space under study, as shown in Fig. 1, where is the scheme of the diffraction of a parallel monochromatic ray of light on a volumetric diffraction grating.

The formation of the diffracted ray obeys the Wulff-Bragg's equation law:

$$
2 L \cdot \sin \Theta=\lambda \text {, }
$$

where $L$ is the distance between particles (step of the diffraction grating), $\Theta$ is the an-

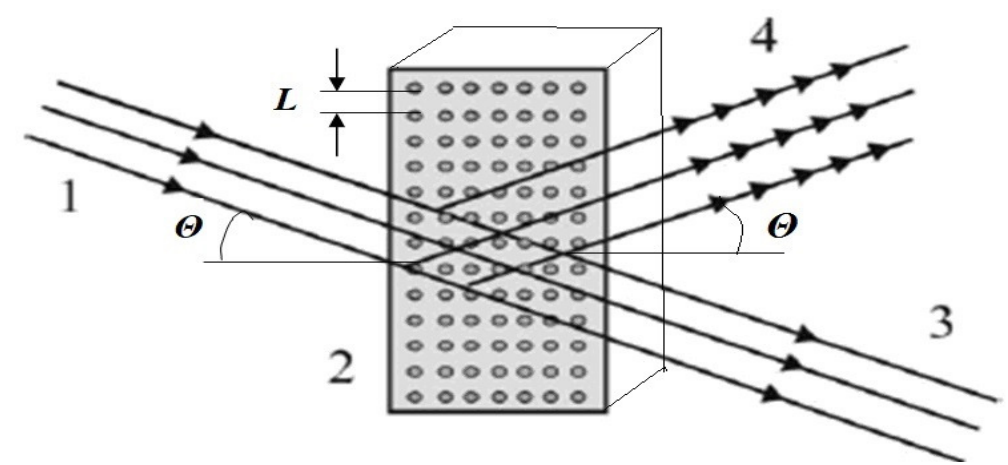

Fig. 1. Diffraction the ray of light on the three-dimensional grating.

1 - Incident ray; 2 - diffraction grating; 3 - transmitted ray; 4 - diffracted ray. 
gle of incidence ray, $\lambda$ is the wavelength of the light ray.

It should be noted that for a three-dimensional grating and monochromatic incident ray (for example, a laser beam) there is only one diffracted ray 4 (see Fig. 1), and it lies in the same plane with the incident 1 and transmitted 3 rays, and its «exit angle» from the grating is equal to the angle of the incident ray $\Theta$ [15]. When monochromatic rays with different directions enter the yolumetric grating, only that diffracted ray will be observed, the propagation direction of which satisfies the WulffBragg's equation. This property, called "angular selectivity", is largely determined by the relative thickness of the grating, expressed as the ratio of the geometric "thickness" to the grating step $h / L$. The larger this value, the pointed is the grating selectivity.

In addition, it follows from [15] that the intensity of the diffracted ray $I$ is proportional to the square of the number of those elements of the grating $N$ that are within the volume $V$ of the intersection of the incident laser beam with the diffraction grating, i.e. $I \sim N^{2}$. In the technique of optical measurements of dispersed systems, such a volume $V$ is called "counting volume". Its value for installations that measure the spatial distribution of light energy $I$ reflected from a collection of grains (or one grain) located at a given time in the "counting volume" is determined by the diameter of the laser beam $D$ and the aperture $\varphi$ of the photodetector. In the first approximation, the "thickness" of the grating is $h \approx D$, and the value of $D$ depends on $V$. For more reliable recording of the diffracted ray (i.e., increasing $I$ ), $V$ should be increased due to the expansion of the aperture $\varphi$, which will lead to an increase in the number of grains $N$, participating in the scattering of light radiation.

Let us take into account that the radiation of the condensed phase of the smoky plasma is recorded by seven photodetectors at angles of $10^{\circ}, 20^{\circ}, 30^{\circ}, 40^{\circ}, 50^{\circ}, 60^{\circ}$, about $70^{\circ}$ of the relative incident ray. It was assumed that if a volumetric diffraction grating of condensed grains appears in the plasma flow, then the recording system of the experimental stand will detect a diffracted light ray by one of seven photodetectors, since they are located in the plane of the incident, transmitted and diffracted rays. Let us calculate what the parameters of the dispersed system should be, namely - the distance between grains (grating constant) $L$ and the numerical concentration grains $n$ for four fractions, which are observed in experiments [4, 16, 2] with dimensions: $10 \mathrm{~nm}, 100 \mathrm{~nm}, 1 \mu \mathrm{m}$ and $30 \mu \mathrm{m}$. From formula (1) it follows that at the wavelength of the "red" laser $\lambda_{R}=0.63 \mu \mathrm{m}$ and various fixed viewing angles $\Theta$, the grating constant $L$ is determined as follows:

$$
L=\lambda / 2 \sin \Theta=0.63 / 2 \sin \Theta
$$

The calculation results for $L$ and $n$ are shown in Table 1 .

As can be seen from Table 1, for detect the diffracted ray, the grating constant $L$ should be about a micron (from $1.8 \mu \mathrm{m}$ to $0.34 \mu \mathrm{m}$ ), and this value depends on the observation angle $\Theta$ (the larger it is, the «denser» the grating). The dependence of the grains concentration $n$ from $\Theta$ is the more significant, then smaller the grains size. So for a fraction of $10 \mathrm{~nm}$, the difference in $n$ takes place by two orders of magnitude (from $1.7 \cdot 10^{17} \mathrm{~m}^{-3}$ at $\Theta=10^{\circ}$ to $2.7 \cdot 10^{19}$ at $\Theta=70^{\circ}$ ). The numerical concentration $n$ of the $30 \mu \mathrm{m}$ fraction is already practically independent of $\Theta$. 
Table 1. Values of the grating constant $L$ and grains concentration $n$ at different scattering angles of the model diffraction grating $\Theta$

\begin{tabular}{|c|c|c|c|c|c|c|c|}
\hline $\begin{array}{c}\Theta, \text { angular } \\
\text { degree }\end{array}$ & $10^{\circ}$ & $20^{\circ}$ & $30^{\circ}$ & $40^{\circ}$ & $50^{\circ}$ & $60^{\circ}$ & $70^{\circ}$ \\
\hline \multicolumn{1}{c|}{$L, \mu \mathrm{m}$} & 1.81 & 0.92 & 0.63 & 0.49 & 0.41 & 0.36 & 0.34 \\
\hline$n(10 \mathrm{~nm}), \mathrm{m}^{-3}$ & $1.7 \cdot 10^{17}$ & $1.2 \cdot 10^{18}$ & $3.8 \cdot 10^{18}$ & $8.0 \cdot 10^{18}$ & $1.4 \cdot 10^{19}$ & $1.9 \cdot 10^{19}$ & $2.7 \cdot 10^{19}$ \\
\hline$n(100 \mathrm{~nm}), \mathrm{m}^{-3}$ & $1.4 \cdot 10^{17}$ & $9.4 \cdot 10^{17}$ & $2.6 \cdot 10^{18}$ & $4.9 \cdot 10^{18}$ & $7.5 \cdot 10^{18}$ & $1.0 \cdot 10^{19}$ & $1.2 \cdot 10^{19}$ \\
\hline$n(1 \mu \mathrm{m}), \mathrm{m}^{-3}$ & $4.5 \cdot 10^{16}$ & $1.4 \cdot 10^{17}$ & $2.3 \cdot 10^{17}$ & $3.0 \cdot 10^{17}$ & $3.6 \cdot 10^{17}$ & $4.0 \cdot 10^{17}$ & $4.2 \cdot 10^{17}$ \\
\hline$n(30 \mu \mathrm{m}), \mathrm{m}^{-3}$ & $3.1 \cdot 10^{13}$ & $3.3 \cdot 10^{13}$ & $3.4 \cdot 10^{13}$ & $3.5 \cdot 10^{13}$ & $3.6 \cdot 10^{13}$ & $3.6 \cdot 10^{13}$ & $3.6 \cdot 10^{13}$ \\
\hline
\end{tabular}

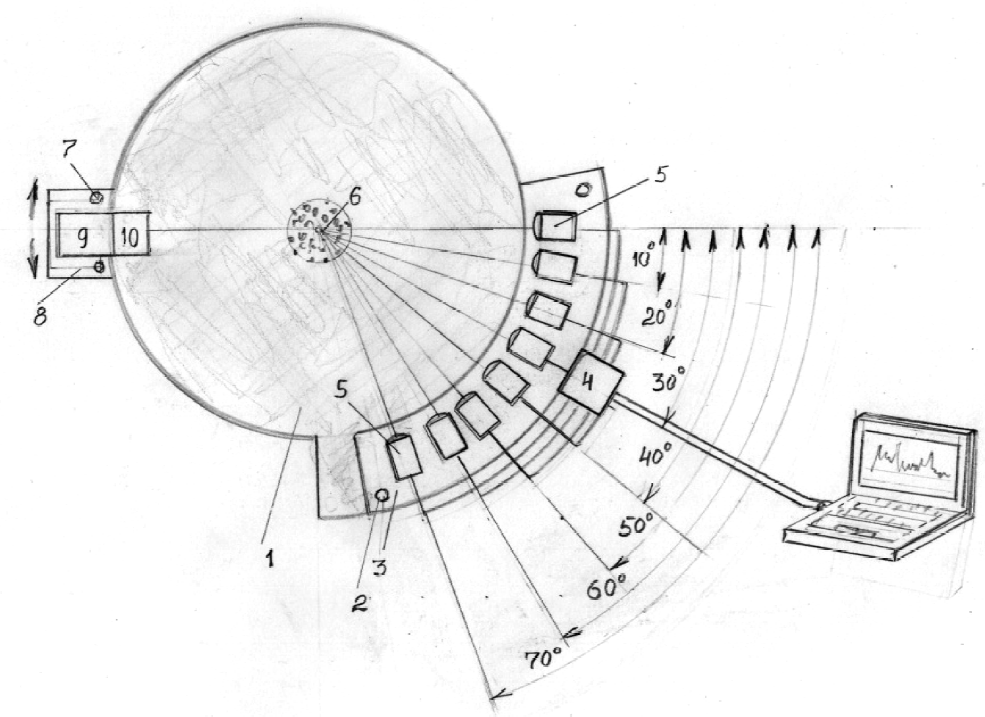

Fig. 2. The experimental stand schematic for measuring the indicatrix of laser radiation scattering by the condensed phase of the smoky plasma:

1 - stand base; 2 - racks for moving and setting the height of the platform 3 with photo detectors $5 ; 4$ - microcontroller unit; 5 - photodetectors ( 8 pcs.); 6 - fuel sample; 7 - movable arm; 8 - table for lasers; 9 - generator for laser diode pumping; 10 - replaceable laser diode mounting compartment.

From these calculations the conclusion follows, that the detection of the "plasma crystal" in the condensed phase is a unique event, the fixation of which is possible only by contemporary experimental methods.

Description of the experimental stand. When developing an experimental stand at the Physics Research Institute of ONU for the study of the spatial structures of condensed phase grains in the heterogeneous smoky plasma by determining the scattering indicatrix of laser radiation, the presence of intense radiation of the plasma flow was taken into account. To exclude it when registering scattered radiation, the probe laser is modulated at a frequency of $60 \mathrm{kHz}$; photodetectors operate at the same frequency. The scheme of the experimental stand is shown in Fig. 2.

As follows from Fig.2, scattered radiation is recorded in the angular sector from 0 to $70^{\circ}$ every $10^{\circ}$ using eight photodetectors (5) and can be adjusted in the range of $0 \div 170$ degrees. The removable compartment (10) contains three laser emitters with 
wavelengths $\lambda_{I R}=808 \mathrm{~nm}, \lambda_{R}=630 \mathrm{~nm}$ and $\lambda_{G}=532 \mathrm{~nm}$. The stand consists of a fixed base 1, on which a table 3 with photodetectors is installed with the help of racks 2 . On the surface of the table there are eight lenses of photodetectors 5 , which are attached to the table with one clamping screw on the racks 2 , which makes it easy to direct the optical axis of each of the lenses towards the center of rotation 6 of the fixed base of the experimental stand.

On the movable arm 7, which can rotate in a circular arc around the center 6 of the fixed base, a table of laser emitters (8) is installed with the help of two racks at the required height on which a generator for the formation of a pulsed pumping current of laser diodes (9) and a removable compartment for attaching these laser diodes (10). The movable arm 7 can be fixed in any required angular position, which allows you to change the orientation of the laser beam relative to the photodetectors, thereby investigating the scattering indicatrix in any angular coordinates with the «angular width of the zone» $70^{\circ}$.

The optoelectronic circuit of the setup includes a control microcontroller 4 connected by a cable to both a generator for generating a pulsed pump current (with a frequency $60 \mathrm{kHz}$ ) of laser diodes (9) and to an external computer. This computer is loaded with a software package that provides measurement data from the microcontroller via the USB interface, as well as their storage in the program format for graphical presentation of the processed experimental results.

When the stand is fully ready for the experiment, the "Ready-Standby" mode is introduced until the flame of the torch for research appears in the working zone. The moment of appearance of a light flash is registered by a flame sensor, from which an automatic procedure for recorded and measuring the parameters of laser beam that has passed through the flame and/or is scattered from the grains of the plasma formation is started. During the first 0.5 second, the software automatically adjusts the dynamic range of the measurement level of the input optical signal in each measuring channel. The end-to-end sensitivity of each of the receiving channels is set, at which the average value of the received signal is equal to half of the entire measurement range. Then, within the next 2.5 seconds, the current values of the transmitted and/or scattered signals are recorded in each of the eight measuring channels with a frequency of 1000 measurements per second (with a dynamic range of $2^{20}$ ), that is, a total of 2500 measurements in each channel.

At the end of the experiment, data is transferred from the stand microcontroller memory through the serial port to the computer. After data transfer, the controller memory is cleared, each of the eight measuring channels is set to zero, and the experimental stand again switches to the "Ready-Standby" mode until the next signal appears.

The saved experiment data in a specific computer file can be viewed and analyzed on a graphic monitor of the special LTspiceXVII program. The working window of the computer with the data processed by this program and displayed in graphical form is shown in the Fig. 3. It shows signals recorded for 2.5 seconds by all channels of the stand when a test glycerin fog is injected into the working area. Curve No. 1 in the fig. 3 corresponds to the signal of the main beam of laser radiation with a wavelength of $\lambda_{I R}=808 \mathrm{~nm}$ on the photodetector No.1. Graphical recording of radia- 


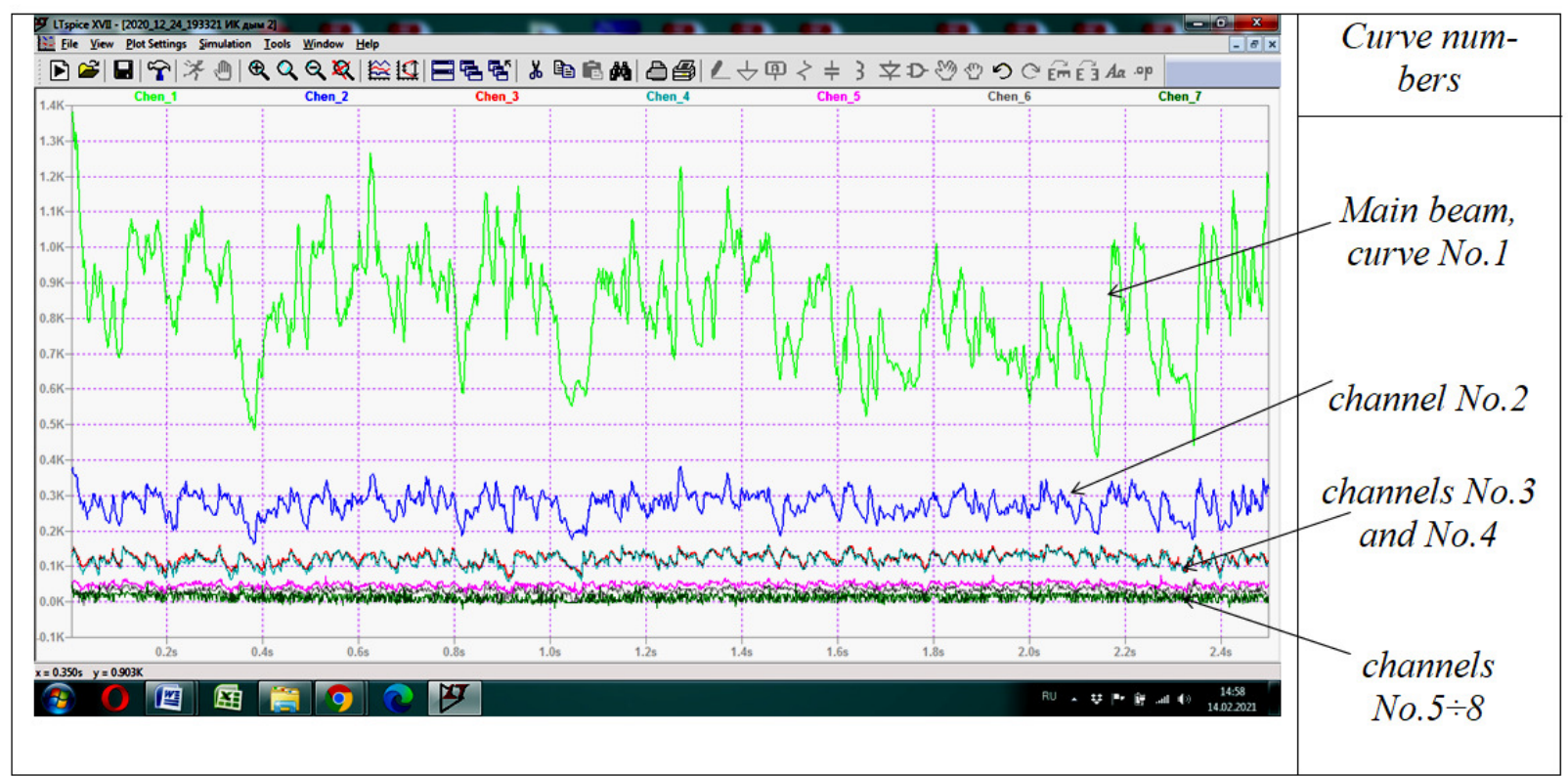

Fig. 3. Passage of the «infrared» laser beam $\left(\boldsymbol{\lambda}_{I R}=808 \mathrm{~nm}\right)$ through the test glycerin fog (curve No. 1 - green). Scattered radiation from glycerin particles on different channels (from No. 2 to No.8) is presented by multi-colored curves No. $2 \div 4$.

tion from glycerin particles on different channels (from No.2 to No.8) are designated $2,3 \ldots 8$. On the computer screen, they are represented by colored curves, and in the upper part of the window there are colored inscriptions of the numbers of the photodetectors. You can programmatically select the desired curve or part of eight curves and display them on the monitor.

Experimental research. A prototype of the special pyrotechnic composition in the form of the cylinder $10^{-1} \mathrm{~m}$ high was placed in the center of the experimental stand (see position 6 in Fig. 2), above which, at the height of $22.510^{-2} \mathrm{~m}$, the platform (3) with recording photodetectors was fixed. (five). The combustion process was recorded on a video camera, the spectral range of "image capture" which extended into the infrared region. При появлении пламени фотодатчиком запускался электронный блок установки, переведенный заранее до эксперимента в ждущий режим. When a flame appeared, the photosensor triggered the electronic unit of the setup, which had been put into standby mode before the experiment. The first 0.5 seconds of burning were used to adjust the electronic unit to the signal levels from all photodetectors, and during the rest of the experiment (about 2.5 seconds), data was accumulated in the stand controller. Then, after the end of the combustion process, the data from the controller were downloaded via the USB port for 3 seconds to the working computer of the stand. In Fig. 4 shows

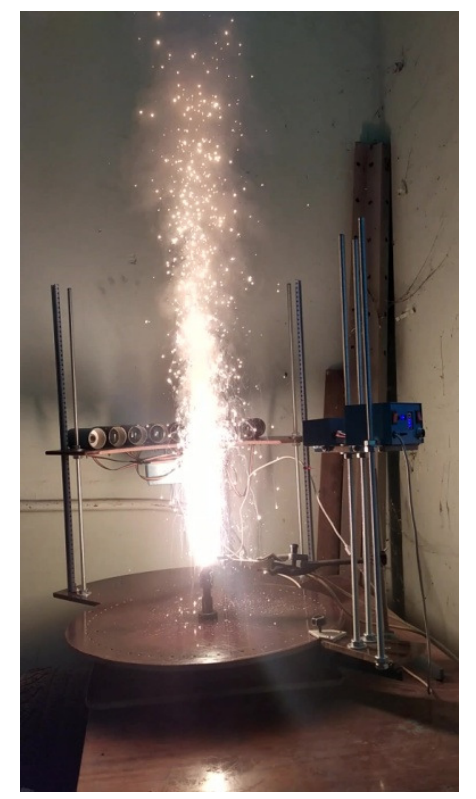

Fig. 4. General view of the flame 


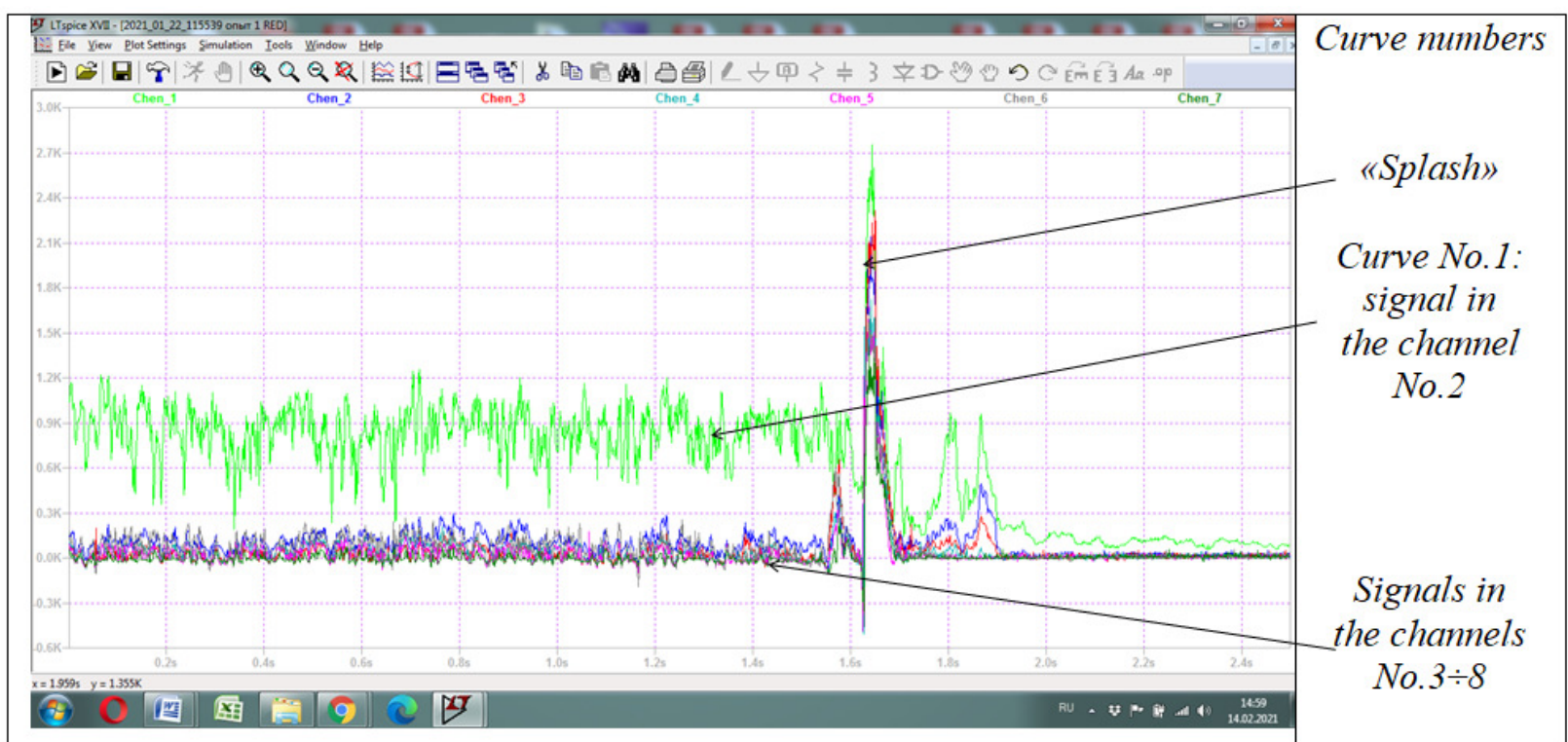

Fig. 5. Curves of scattered laser radiation with a wavelength of $\lambda_{R}=630 \mathrm{~nm}$ when passing through the flame

a general view flame from the pyrotechnic composition.

Computer processing of the information showed that in $\approx 2.1$ seconds after the beginning of the combustion process, a significant «splash» of the intensity of radiation scattered from the particles of smoky plasma, recorded by the photodetectors of all seven channels, is visible (see Fig. 5).

In this case, the first channel, which records the attenuation of the main laser beam as it passes through the flame, did not detect the burst (this curve is not shown in Fig. 5).

Curve No.1 (green), corresponding to a signal recorded at an angle of $10^{\circ}$ relative to the main beam, has the highest amplitudes of laser radiation scattered by smoky plasma grains with a wavelength of $\lambda_{R}=630 \mathrm{~nm}$.

From Fig. 5 can be seen that the averaged signal amplitude before the «splash» (up to the moment of time $\approx 1.6 \mathrm{~s}$. From the beginning of the combustion process + $0.5 \mathrm{~s}$ ) was about $1.2 \div 1.3$ conventional units (determined by the process of electronic "splitting" signal). The amplitude of the «splash» of the signal was about 2.7 conventional units, which is almost 2 times more than the average value. «Splashes» of the same order were observed at other observation angles (by other photodetectors), but with a lower intensity. As noted above, the first photodetector on the "main" axis of the laser beam did not register any splashes of signal intensity.

One of the explanations for this effect can be the scattering of the laser beam on a volumetric diffraction grating consisting of grains of a condensed phase, such as a "dusty crystal", which emerged situationally in the plasma flow.

It should be noted that in experiments with a "red" laser $\left(\lambda_{R}=630 \mathrm{~nm}\right)$, a «splash» in the scattered radiation curves was observed only once. When using an infrared laser $\left(\lambda_{I R}=808 \mathrm{~nm}\right)$, the «splash» was not recorded. Most likely, this is due to the uniqueness of the event of the formation of «dust crystals», which emphasizes the need for comprehensive researches of the properties of the smoky plasma formed in the combustion products of pyrotechnic compositions. 


\section{References:}

1. Arhipov V.A., Bondarchuk S.S. Optical methods for diagnostics of heterogeneous plasma of combustion products - Tomsk: Tomsk State University, 2010. $265 \mathrm{p}$.

2. Vlasov V.A., Mishkin V.F., Tihomirov I.A. Determination of the dispersion of the heterogeneous plasma condensed phase // Bulletin of the Tomsk Polytechnic University. - 2003. - V. 306. - № 6. - C. 42-46.

3. Dragan G. S. et all. Experimental study of the condensed disperse phase of combustion products of solid fuel // Proc. of the scient. and techn. meet., AlmaAta, 25-31 October, 1982, (IVTAN). - Moscow, USSR. - 1984. - P.191-192.

4. Vishnyakov V. I., Dragan G. S. Ordering spatial structures of dust grains in the thermal plasma // Phys. Rev. - 2006. - V. 2. - P. 1-7.

5. Pollock E. L., Hansen J. P.. Statistical Mechanics of Dense Ionized Matter II. Equilibrium Properties and Melting Transition of the Crystallized OneComponent Plasma // Phys. Rev. - 1973. - V. 8, no. 6, P. 3110-3122.

7. Ikezi H. Coulomb solid of small particles in plasmas. // Phys. Fluids. - 1986. V. 29, no. 6, P. 1764-1766.

8. Chu J. H., Lin I. Direct observation of Coulomb crystals and liquids in strongly coupled rf dusty plasmas // Phys. Rev. Lett. - 1994. - V. 72, no. 25, P. 40094012.

9. Thomas H., Morfill G. E., Demmel V., Goree J., Feuerbacher B., Möhlmann D.. Plasma Crystal: Coulomb Crystallization in a Dusty Plasma // Phys. Rev. Lett. - 1994. - V. 73. - P. 652.

10. Fortov V. E., Morfill G. E. Complex and Dusty Plasmas: From Laboratory to Space. - Boca Raton: CRC Press, 2010. - 312c.

11. Dragan G. S. Electroacoustic oscillations of aluminum oxide particles in the thermal plasma // JETP. - 2004. - V.98. - No. 3. - P. 503-507,

12. Vishnyakov V. I., Dragan G. S. Electrostatic interaction of charged planes in the thermal collision plasma. Detailed investigation and comparison with experiment // Phys. Rev. - 2005. - E 71. - No. 1. - P. 1-9.

13. Dragan G.S. Dusty and smoky plasmas. Some properties and applications // Ukr. J. Phys. - 2005. - V. 50. - No. 2. - P. 130-134.

14. Vishnyakov $V$. I., Dragan G. S. Florko A. V. The formation of negatively charged particles in thermoemission plasmas // JETP. - 2008. - V. 106. N.1. P. 182-186.

15. Vishnyakov V.I., Dragan G.S. Coupling parameter for the low-temperature plasma with condensed phase // Condensed Matter Phys. - 2007. -V.10. - No 2. - P.201-208.

16. Ryabuho V.P.,Perepelicina O.A. Diffraction of light by volumetric diffraction gratings. - Saratov: N.G.Chernishevskiy Saratov University, 2014. - 19 p.

17. Dragan G.S. Thermodynamics and electrodynamics of interphase interactions in the plasma of combustion products of metallized compositions, solid and gaseous fuels. Dissertation for the academic title: Doctor of the Physical and Mathematical Sciences. Odessa. - 2004. - 341p. 
Драган Г.С., Сантоний В.И., Шингарёв Г.Л., Римашевский А.А., Колесников К.В., Шевченко О.Н., Янко В.В.

Рассеяние лазерного излучения конденсированной фазой гетерогенной дымовой плазмы

\begin{abstract}
АННОТАЦИЯ
Проведен обзор проблемы регистрации упорядоченной структуры с дисперсной фазы в плазменных образованиях, где показано, что в экспериментах с газоразрядной плазмой, содержащей монодисперсные конденсированные частищь, были обнаружены «плазменные кристалль». Разработана методика исследования пространственных структур частии конденсированной фазы в гетерогенной дымовой плазме путём определения индикатрисы рассеяния лазерного излучения, модулированного с частотой 60 кГи в трёх спектральных интервалах. Создана экспериментальная установка для регистрации индикатрисы рассеяния лазерного излучения на длинах волн $808 \mathrm{нм}, 630$ нм и 532 нм в интервале углов рассеяния от 0 до 170. Разработана программа регистрачии и обработки результатов измерений на компьютере. Проведень испьтания экспериментального комплекса на факеле пиротехнических композиций. Обнаружен максимум рассеянного лазерного излучения, который может свидетельствовать о ситуативном появлении «плазменного кристалла» в дымовой плазме. Обнаружено пиковое увеличение интенсивности рассеянного излучения. Сделаны выводы о необходимости комплексных исследований свойств дымовой плазмы, образованной в продуктах сгорания пиротехнических составов.
\end{abstract}

Ключевые слова: Гетерогенная плазма, рассеяние лазерного излучения, пространственные структуры частии в плазме.

\title{
Драган Г.С., Сантоній В.І., Шингарьов Г.Л., Рімашевський О.А., Колесніков К.В., Шевченко О.М., Янко В.В. \\ Розсіювання лазерного випромінювання конденсованої фазою гетерогенної димової плазми
}

\begin{abstract}
АНОТАЦІЯ
Проведено огляд проблеми реєстрації впорядкованої структури з дисперсної фази в плазмових утвореннях, де показано, що в експериментах з газорозрядної плазмою, щцо містить монодисперсні конденсовані частки, були виявлені «плазмові кристали». Однак в димової ( $i$ пиловий) плазмі фіксувався тільки одиничний факт, щэо спостерігається в відібраної на скляну підкладку продуктів горіння піротехнічних композииій. Розроблено методику дослідження просторових структур частинок конденсованої фази в гетерогенної димової плазмі иляхом визначення індикатриси

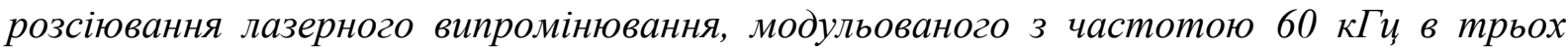
спектральних інтервалах. Створена експериментальна установка для реєстрації індикатриси розсіювання лазерного випромінювання на довжинах хвиль 808 нм, 630 нм i 532 нм в інтервалі кутів розсіяння від 0 до $170^{\circ}$ з тривалістю вимірювань 3 сек. Розроблено програму реєстрачії та обробки результатів вимірювань на комп'ютері. Проведено випробування експериментального комплексу на факелі металізованих паливних композицій. Виявлено пікове збільшення інтенсивності розсіяного випромінювання. Зроблено висновки про необхідність комплексних досліджень властивостей димової плазми, утвореної в продуктах згорання піротехнічних складів.
\end{abstract}

Ключові слова: Гетерогенна плазма, розсіювання лазерного випромінювання, просторові структури частинок в плазмі. 